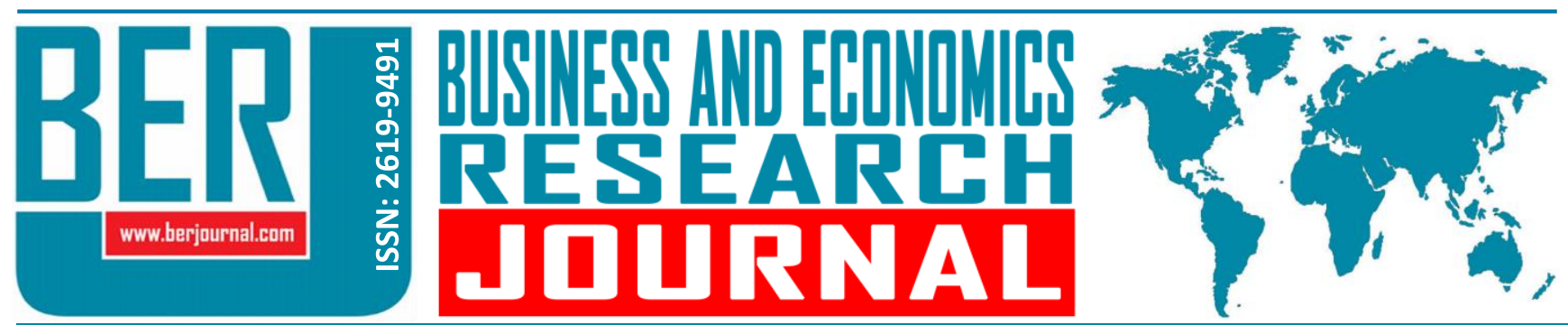

Business and Economics Research Journal Vol. 9, No. 3, 2018, pp. 579-588 doi: 10.20409/berj.2018.124

\title{
Effect of Mandatory IFRS Adoption on Cost of Debt in Turkey
}

\section{Hakan Ozkaya ${ }^{a}$}

Abstract: The ultimate aim of financial reporting is the communication between companies and their stakeholders. To better serve this ultimate aim, International Accounting Standards Board (IASB) required all European Union listed companies to adopt International Financial Reporting Standards (IFRS) starting from January 1, 2005. Some of other emerging countries like Turkey also complied with this requirement. In this paper, whether mandatory adoption of IFRS in 2005 caused a decrease in average cost of debt of Turkish manufacturing firms or not is tested. A cross-section fixed effect panel model was employed for a data set of 138 companies and 646 firm-year observations between years 2002 and 2008. Results show that firms in the sample have a significantly lower cost of debt after adoption year. Moreover, while; firm size, current ratio, GDP growth and interest rates have a positive association with the cost of debt, tangibility and interest coverage have a negative effect on the cost of debt.
Keywords: IFRS Adoption, Cost of Debt, Financial Reporting, Information Asymmetry, Determinants of the Cost of Debt

JEL: M41, M48

$\begin{array}{ll}\text { Received } & : 15 \text { March } 2018 \\ \text { Revised } & : 18 \text { May } 2018 \\ \text { Accepted } & : \text { 31 May } 2018 \\ \text { Type } & \text { : Research }\end{array}$

\section{Introduction}

For the aims of; contributing to a better functioning of the internal market, ensuring the high level of transparency and comparability of financial reporting, building an integrated capital market, contributing to the efficient and cost-effective, smoothly and efficiently functioning of the capital markets, enhancing the competitiveness of capital markets, all publicly traded companies in European Community were required to prepare their financial statements in accordance with International Accounting Standards (IAS), at the latest by 2005 (European Community Regulation No. 1606/2002). Capital Markets Board of Turkey (CMB) also required all listed companies prepare their financial statements in accordance with IFRS starting from the year 2005 by issuing the Communiqué Serial XI, No: 25 in 2003. Thus mandatory IFRS adoption also took place in 2005 for Turkish listed companies in line with all EU-listed companies.

IFRS is getting more and more widely used by countries all over the world every day. As of March 2017, 126 jurisdictions require all or most publicly accountable entities to use IFRS standards in financial reporting, and an additional 13 authorities permit or require IFRS Standards for not all or most but at least some domestic publicly accountable entities (IFRS Foundation, 2018).

Adoption of uniform and higher quality standards by many countries is expected to enhance comparability and improve the information content of financial statements. Transparency and reliability of financial information are also expected to improve as a more detailed financial reporting system is adopted. Horton, Serafeim, and Serafeim (2013) conclude that mandatory adoption of IFRS improves quality of 
information environment measures like forecast accuracy. They argue that the improvement in the information environment can be attributed to the improved quality of information content and accounting comparability. As information content and quality improves, information asymmetry decreases and risk estimation gets easier, and firms enjoy lower rates of cost of capital. Thus outside information users like investors and creditors demand lower levels of risk premium in their return rates. This improvement intuitively leads us to expect lower rates for the cost of equity and cost of debt for firms who adopt IFRS in reporting their financial information.

Although accounting information plays a more direct role in debt markets than equity markets, studies that concentrate on effects of IFRS on equity markets are more widespread, and studies examining the effect of IFRS adoption on debt markets are rare (Moscariello, Skerratt, \& Pizzo, 2014). This paper aims to test whether the average cost of debt of Turkish manufacturing firms decreases after IFRS adoption in 2005. Besides the determinants of the cost of debt for Turkish manufacturing firms are also tested since they are used as control variables in our model.

Adoption of IFRS by firms of different countries from all over the world is a harmonization process. Understanding this harmonization process and its effects on economic aspects of adopters are crucial. Besides harmonization process, understanding the dynamics of the cost of debt is even more important for countries like Turkey where debt financing is one of the primary ways of financing of assets. Literature review reveals that impact of IFRS adoption on the cost of debt of Turkish firms was not examined economically before. Thus, this paper will be first to shed light on this hypothesized relationship between financial reporting regime change and cost of debt burdened by Turkish firms.

Here it should be noted that Turkish firms used to prepare their financial statements in accordance with General Communique on Accounting System Application issued by Turkish Ministry of Finance and Turkish Tax Law before IFRS adoption. Upon adoption of IFRS, firms began to record their borrowing costs in accordance with IAS 23 Borrowing Costs Standard. IAS 23 states that "borrowing costs that are directly attributable to the acquisition, construction or production of a qualifying asset form part of the cost of that asset" (IAS 23: 1). On the other side, Turkish Tax Law does not make the distinction of "qualifying asset" and states that firms must capitalize borrowing costs of acquisition period and they are free to choose either to capitalize or to recognize as period cost for the borrowing costs in the rest of the periods (Küçüktüfekçi \& KIllı, 2016). We see that IAS 23 is more conservative about recognizing borrowing costs as an asset than Turkish Tax Law. This difference alone might affect the general level of cost of debt of pre and post IFRS period. The change in the cost of debt after IFRS adoption includes both changes stem from recording/recognizing and those stem from the judgment of creditors. How much portion of change can be attributable to each underlying dynamic is beyond the scope of this study.

The rest of the paper is organized as follows: In the following section, the relevant literature is summarized. Methodology and data section introduces the model to be tested and explains the variables in the model. Data elimination process, data sources and descriptive statistics are presented under data section. Econometric specifications and regression results are presented in the results section. Finally, results are summarized and discussed in conclusion section.

\section{Literature Review}

The effect of IFRS adoption was examined by many researchers. For an extensive review of empirical studies, please see Lourenço, Branco and Castelo (2015) and Zaidi and Paz (2015). They conclude that IFRS adoption has positive impacts on information quality, the capital market, analysts' ability to predict, comparability, and information use. Armstrong, Barth, Jagolinzer and Ried (2010) examined the reaction of 18 European stock markets to IFRS adoption-related events. Their overall findings show that IFRS adoption in Europe was associated with decreases in information asymmetry, more rigorous enforcement of the standards and convergence in the eyes of the investors. Authors like Kim, Tsui and Yi (2011) argue that voluntary adoption of IFRS would deliver a credible signal on how much trustworthy is the adopter. The credibility of the signal given by the commitment stems from its cost. The "cost" here refers to the relative 
cost burdened by an adopter while its competitor does not accept the burden. In the case of compulsory adoption, the relative cost would be marginal, thus would not lead a credible signal for the commitment. When a company voluntarily adopts IFRS, this adoption gives a stronger signal on the confidence of that company in its records. Paglietti (2009) tests the impact of mandatory IFRS adoption on accounting quality and reports an overall increase in the value relevance in IFRS period for Italian listed firms.

Most researchers argue that effects of adoption of internationally recognized accounting standards like IFRS or U.S. GAAP are examined heavily in equity markets but rarely in debt markets (Wu \& Zhang, 2014; Moscariello et al., 2014). Sengupta (1998) was one of the earliest researchers who relates disclosure quality and cost of debt. He shows that higher disclosure quality ratings lead to a lower cost of debt. Timely and detailed disclosures reduce the perception of default risk. In recent years, studies on the association of IFRS and debt financing are more abundant. It makes more sense that voluntary adoption of IFRS is considered as a more credible signal by market players because it is a costly way of conveying more financial information to companies' stakeholders. Therefore voluntary adoption of IFRS and its effect on the cost of debt is one of the research areas. Kim et al. (2011) present international evidence on voluntary IFRS adoption and loan markets. They report that banks charge about 20 basis points lower loan rates for all loans and 31 basis point lower loan rates for LIBOR-based loans to IFRS adopters than non-adopters. Lee, Kang and Cho (2015) also examine only the voluntary adoptions of IFRS by Korean firms and they report that cost of debt is lower for IFRS adopters. Florou and Kosi (2015) report that higher quality financial reporting are responded positively by debt providers and mandated IFRS adoption yields positive economic consequences regarding the cost of debt. Wu and Zhang (2014) relate financial reporting standards and cost of debt indirectly. They provide evidence that both mandatory (for strong law countries) and voluntary internationally recognized accounting standards (IFRS/U.S. GAAP) adoption are associated with higher credit ratings. Florou, Kosi and Pope (2017) also investigate the effect of mandatory IFRS adoption on credit ratings and they report improvements in credit relevance following IFRS adoption for firms in 17 countries.

Effects of IFRS adoption were also examined from many aspects of Turkish firms. Balsari and Varan (2014) provide a comprehensive literature review on IFRS related literature in Turkey between 2005 and 2014. Their overall assessment reveals a positive impact of IFRS adoption on Turkish capital markets. Employing event study method, Gürarda (2013) analyzes the market reactions to adjusted earnings of ISE-30 firms after the IFRS adoption. Adıgüzel (2017) reports decreases in accrual management and increases in earnings quality upon IFRS adoption by Turkish firms. Value relevance of financial information in pre and the post-IFRS period was relatively more heavily examined for Turkish firms. Balsari, Özkan and Durak (2010) investigate the impact of IFRS adoption on the earnings conservatism and conclude that IFRS adoption has increased both the timeliness and earnings conservatism. Kargin (2013) analyzes the impact of IFRS adoption on the relevance of book value and earnings and her results reveal an improved value relevance in the postIFRS period. Suadiye (2012) analyzes the impact of IFRS adoption on the value relevance of earnings and book values of equity and concludes that IFRS adoption increased the value relevance of accounting information for Turkish listed firms. The review of empirical studies by Balsari and Varan (2014) concludes that IFRS adoption improved value relevance and accounting quality for Turkish listed companies. Türel (2009) is another paper examines the value relevance of IFRS for Turkish firms and he confirmed that the value relevance of earnings and book value of equity had increased significantly after IFRS adoption.

Communiqué for Accounting Standards in Capital Market (Serial: XI, No: 25) by Capital Market Board which required listed companies prepare and present their financial statements in accordance with IFRS no later than 2005 was released in 2003. So years between 2003 and 2005 was a transition period for Turkish firms. Firms, which adopted IFRS in their financial reporting before 2005, are called early adopters or voluntary adopters. There are some papers in the literature, which focus on early adopters of IFRS. Bozcuk (2012) investigates the effects of voluntary adoption of IFRS by Turkish firms and she reports significantly higher performance measures for early-adopters. Another paper that investigates early adopters in Turkey is Senyigit (2014). This paper examines the determinants of voluntary IFRS adoption of listed firms in Turkey and reports; size, international exposure and type of auditor as the main drivers of adoption. 
Some authors analyzed the impact of the transition to IFRS on the financial statements by comparing the accounts on the statements or by comparing the ratios based on pre and post IFRS period financial statements. Ağca and Aktaş (2007) were one of the first to analyze and posit the economic changes in the balance sheets of Turkish firms before and after the adoption. Alkan and Doğan (2012) also report significant differences between ratios before and after IFRS adoption. Terzi and Şen (2013) analyze the effects of IFRS adoption on the owners' equity accounts of Turkish manufacturing firms and report the significant differences in accounts. Dalcı and Özyapıcı (2017) investigate the impact of IFRS adoption on liquidity, solvency, and profitability ratios of the hotels listed in ISE in Turkey. Their results show that IFRS adoption has no significant impact on selected financial ratios.

Cost of debt was considered only theoretically in the context of IFRS in Turkey. Among many, Karatas (2010) compares and discusses borrowing costs in the context of IAS 23, IFRS for SMEs and Turkish Tax Law. Gönen and Akça (2014) compare and contrast the cost of debt regarding tax regulations and IFRS. None of these papers provides analysis on the economic consequences of IFRS on the cost of debt and quantitative comparison between pre and post-IFRS period.

\section{Methodology and Data}

\subsection{The Model}

Dummy variable approach is one of the most widely used techniques to assess the effect of IFRS adoption after a certain date. Most papers took the dummy variable inclusion as a way to analyze the pre and post IFRS situation on a specific dependent variable. The single dummy model as shown below in Equation 1 tests the impact of IFRS adoption on the cost of debt.

$$
\begin{aligned}
& \text { CostofDebt }_{j, t}=\alpha+\text { IFRSDummy }_{t}+\gamma_{1} \cdot \text { LogofSales }_{j, t}+\gamma_{2} \text {. CurrentRatio }_{j, t}+ \\
& \gamma_{3} . \text { Tangibility }_{j, t}+\gamma_{4} \cdot \text { LogInterestCoverage }_{j, t}+\gamma_{5} \cdot \text { LogStDevNetIncome }_{j, t}+ \\
& \text { GDPGrowth }_{t}+\text { IntRate }_{t}+\varepsilon_{j, t}
\end{aligned}
$$

\subsection{Variables}

The dependent variable "CostofDebt" is measured by interest expense of firm $\mathrm{j}$ in year $\mathrm{t}$, divided by average total debt of firm $j$ in year $t$. This measure is commonly used by the previous work like (Francis, LaFond, Olsson, and Schipper (2005), Moscariello et al. (2014), etc.). The explanatory variables are IFRSDummy and other control variables, which are commonly used in the literature for explaining the cost of debt. "IFRSDummy" is the focus of interest explanatory variable, which takes the value of 1 for the post-IFRS period and 0 otherwise. The significant and negative coefficient of "IFRSDummy" implies that IFRS adoption is associated with lower cost of debt.

Seven control variables are used in the model. The first control variable is firm size measured by the log of total sales. "LogSales" is expected to be inversely related to cost of debt. The second control variable of the model is "Tangibility." Tangibility is the proxy for the availability of collaterals in case of default of the debt. Tangibility is measured as the ratio of the net of property, plant and equipment to total assets. Since more collateral gives more security to the lender, this variable is expected to have a negative association with the cost of debt. "CurrRatio" is the third control variable of the model. CurrRatio is measured as current assets divided by current liabilities. The current ratio is one of the common measures of firm's liquidity and power of fulfilling its current obligations. CurrRatio variable is expected to be inversely related to cost of debt. The fourth control variable is "LogIntCov", which is a proxy for how easily a firm can pay the interest on its debt. Interest coverage ratio is measured as the log of earnings before interest and taxes (EBIT) divided by the interest expense. Since interest coverage ratio shows how many times a firm can pay its interest expenses by its earnings before interest and taxes (EBIT), cases of negative earnings before interest and taxes were excluded. The fifth control variable "LogSDNetInc" is the proxy for income volatility hence a proxy for firm-specific risk. LogSDNetInc is measured as the log of the standard deviation of net income over the rolling 
prior three-year period. In the literature, this proxy is estimated by using five-year period. To keep the sample size bigger, a three-year period is used in the estimations. Although not reported here, using of the five-year version of the variable did not change the results significantly. To control for the macroeconomic effects on the cost of debt, "GDPgrowth" which is a widely used variable, was included in the model. GDPGrowth is the annual percentage growth rate of GDP at market prices based on constant local currency. The last control variable "IntRate" was included to control the effect of interest rates on the cost of debt. IntRate is the upper bound for annual interest rate allowed by the Central Bank of Turkey for time deposit up to 6 months.

\subsection{Data}

All the data used in this study are publicly available. All of the firm-specific variables are taken from Worldscope Database for Turkish manufacturing firms (i.e., SIC Codes between 20 and 39). GDPgrowth data is taken from World Development Indicators of World Bank Database and IntRate data is taken from Central Bank of the Republic of Turkey (CBRT).

Because our data have both a cross-section dimension of companies and a time dimension of years, estimation techniques used for panel data is more appropriate. First of all, using of panel data enables one to control for heterogeneity of companies. Second, cross-section dimension of companies add a lot of variabilities and decrease the collinearity among the variables, add more degree of freedom and thus add more efficiency to estimations. Third, panel data has more dynamic structure when compared with the stable nature of cross-section data. Fourth, panel data is more capable of capturing effects that are not detectable in pure cross-section or pure time-series data. (Baltagi, 2005: 4-6).

A firm-year panel data of Turkish manufacturing firms was used to test the effect of IFRS adoption on the cost of debt. Years between 2002 and 2008 is chosen as the period of the study. Since the adoption year is 2005, an equal number of years was chosen before and after the adoption year. 2002 was chosen as the starting year of the period for two reasons. First of all, Turkey experienced two very big financial crises in years 1999 and 2001. These crises distorted financial reports of many companies and jeopardized their comparability to financial reports of subsequent years. The second reason for choosing the 2002-2008 period is comparability to other studies since this period was also chosen by other studies like Moscariello et al. (2014).

Data elimination process started with eliminating firm-year observations with any missing values for variables used in the model during through the chosen period. Next, outliers were eliminated based on variables' histograms and distribution characteristics. Data elimination procedure yielded enhanced the skewness and kurtosis values for variables substantially and yielded 138 companies and 646 firm-year observations in the sample.

Table 1 shows key descriptive statistics for variables in the model. The mean value of the dependent variable of the model, the cost of debt burdened by the sample companies is 0.19 with a standard deviation 0.18 . The mean value of the logarithm of sales is 5.48 and the mean value of tangibility variable is 0.37 . The average current ratio is 2.02 while the logarithm of average interest coverage ratio is 1.72 for the sample. The mean value for the standard deviation of net income over the rolling prior four-year period is 2.04 while the mean interest rate is 26.34 for the sample. The skewness and kurtosis measures of the variables indicate no extreme distribution characteristics (Kline, 2010:63).

Variables in the model were checked for whether they have a unit root or not. Panel unit root tests were run for all variables in the model. All of the variables are found to be stationary according to results of all tests, namely; Levin, Lin \& Chu, Im, Pesaran \& Shin, ADF - Fisher and PP - Fisher. 
Table 1. Descriptive Statistics

\begin{tabular}{|l|c|c|c|c|c|c|c|}
\hline & Mean & Median & Max. & Min. & St.Dev. & Skew. & Kurt. \\
\hline Dependent variable & \multicolumn{7}{|l|}{} \\
\hline CostofDebt & 0.19 & 0.13 & 0.95 & 0.01 & 0.18 & 1.77 & 6.20 \\
\hline Independent variables & \multicolumn{7}{|l|}{} \\
\hline IFRSDummy & 0.59 & 1.00 & 1.00 & 0.00 & 0.49 & -0.37 & 1.14 \\
\hline LogSales & 5.48 & 5.26 & 10.93 & -0.17 & 1.52 & 0.60 & 3.82 \\
\hline Tangibility & 0.37 & 0.38 & 0.86 & 0.00 & 0.18 & 0.06 & 2.34 \\
\hline CurrRatio & 2.02 & 1.59 & 8.28 & 0.07 & 1.29 & 1.85 & 6.78 \\
\hline LogIntCov & 1.72 & 1.42 & 12.36 & -4.55 & 1.88 & 1.34 & 6.97 \\
\hline LogSDNetInc & 2.04 & 2.02 & 6.90 & -2.65 & 1.55 & 0.03 & 3.11 \\
\hline GDPGrowth & 6.37 & 6.43 & 9.64 & 0.85 & 2.64 & -0.72 & 2.92 \\
\hline IntRate & 26.34 & 18.41 & 53.44 & 17.17 & 13.41 & 1.25 & 2.85 \\
\hline COSO
\end{tabular}

"CostofDebt" is the interest expense divided by average total debt. IFRSDummy takes the value of 1 for the post-IFRS period and 0 otherwise. "LogSales" is the log of total sales. "Tangibility" is the ratio of the net of property, plant and equipment to total assets. "CurrRatio" is the current assets divided by current liabilities. "LogIntCov" is the log of earnings before interest and taxes (EBIT) divided by the interest expense. "LogSDNetInc" is the log of the standard deviation of net income over the rolling prior three-year period. GDPGrowth is the annual percentage growth rate of GDP at market prices based on constant local currency. IntRate is the upper-bound for annual interest rate allowed by the Central Bank of Turkey for time deposit up to 6 months.

Table 2 shows the distribution of observations in years. As seen not all of the data for all companies are present throughout the sample period. Some or all of the data for required variables of some companies are missing in some of the years. Thus the data is an unbalanced or incomplete panel. At this point whether to continue the analysis with panel data or not should be decided. The unbalanced data would not be a problem as long as it is incomplete due to randomly missing observations (Baltagi, 2005: 165). The test proposed by Verbeek and Nijman (1992) was carried out as it was described by Baltagi (2005: 229) to test whether there is a sample selection problem or not. Namely, three variables were generated where the first variable is a dummy variable, which takes the value of 1 if a company is observed in the previous period, and 0 otherwise. The second variable is also a dummy variable that takes the value of 1 if a company is observed in all periods, and 0 otherwise. The third variable is the number of periods in which a company is observed. These variables are included in our model and tested whether any of these variables are significant. They were found insignificant which indicates that there is no sample selection problem. Thus analyses were continued with the unbalanced panel structure.

Table 2. Distribution of Observations in Years

\begin{tabular}{|c|c|c|c|c|c|c|c|c|}
\hline Year & $\mathbf{2 0 0 2}$ & $\mathbf{2 0 0 3}$ & $\mathbf{2 0 0 4}$ & $\mathbf{2 0 0 5}$ & $\mathbf{2 0 0 6}$ & $\mathbf{2 0 0 7}$ & $\mathbf{2 0 0 8}$ & Total \\
\hline $\begin{array}{c}\text { Number of } \\
\text { Observations }\end{array}$ & 80 & 85 & 99 & 97 & 95 & 109 & 81 & 646 \\
\hline $\begin{array}{c}\text { Number of } \\
\text { Observed Years }\end{array}$ & $\mathbf{1}$ & $\mathbf{2}$ & $\mathbf{3}$ & $\mathbf{4}$ & $\mathbf{5}$ & $\mathbf{6}$ & $\mathbf{7}$ & Total \\
\hline $\begin{array}{c}\text { Number of } \\
\text { Companies }\end{array}$ & - & 20 & 23 & 25 & 15 & 23 & 32 & $\mathbf{1 3 8}$ \\
\hline
\end{tabular}

Pearson correlations between variables were calculated to check for multicollinearity. Table 3 presents the correlation matrices for the variables. All the correlation values are well below the critical limits. Thus the multicollinearity in the independent variables would not be a serious problem. 
Table 3. Correlation Matrice

\begin{tabular}{|c|c|c|c|c|c|c|c|c|}
\hline & 1 & 2 & 3 & 4 & 5 & 6 & 7 & 8 \\
\hline CostofDebt & 1.00 & & & & & & & \\
\hline LogSales & -0.25 & 1.00 & & & & & & \\
\hline CurrRatio & 0.06 & -0.10 & 1.00 & & & & & \\
\hline Tangibility & -0.15 & -0.02 & 0.02 & 1.00 & & & & \\
\hline LogIntCov & -0.19 & 0.11 & 0.61 & 0.09 & 1.00 & & & \\
\hline LogSDNetInc & -0.17 & 0.71 & -0.06 & 0.10 & 0.15 & 1.00 & & \\
\hline GDPGrowth & 0.02 & -0.11 & -0.03 & 0.04 & 0.00 & -0.16 & 1.00 & \\
\hline IntRate & 0.41 & -0.13 & -0.09 & -0.09 & -0.15 & -0.06 & -0.15 & 1.00 \\
\hline \multicolumn{9}{|c|}{$\begin{array}{l}\text { "CostofDebt" is the interest expense divided by average total debt. "LogSales" is the log of total } \\
\text { sales. "Tangibility" is the ratio of the net of property, plant and equipment to total assets. } \\
\text { "CurrRatio" is the current assets divided by current liabilities. "LogIntCov" is the log of earnings } \\
\text { before interest and taxes (EBIT) divided by the interest expense. "LogSDNetInc" is the log of the } \\
\text { standard deviation of net income over the rolling prior three-year period. GDPGrowth is the } \\
\text { annual percentage growth rate of GDP at market prices based on constant local currency. } \\
\text { IntRate is the upper-bound for annual interest rate allowed by the Central Bank of Turkey for } \\
\text { time deposit up to } 6 \text { months. }\end{array}$} \\
\hline
\end{tabular}

\section{Results}

The effect of IFRS adoption on the cost of debt was tested by estimating Equation 1 over the period 2002-2008. Baltagi $(2005: 12,14)$ states that the fixed effect model is the appropriate specification when the sample is comprised of firms, OECD countries or American states, etc. The random effects model is an appropriate specification if companies are randomly drawn from a large population. The Hausman test was run to choose between the fixed and random effects estimators. The null hypothesis that assumes exogeneity of all the regressors with the random individual effects was strongly rejected (Chi-Square Statistic of 48.12 with a degree of freedom of 8). Thus using fixed effect model for our sample which is comprised of BIST companies between 2002 and 2008 would be appropriate. Moreover, since the Durbin-Watson Statistic of 1.939 is higher than the upper bound of 1.757 in Durbin-Watson Significance Table of Savin and White $(k=8, n=200)$, we would not reject the null hypothesis of non-autocorrelated errors. Cross-section GLS weights were used for the estimations to account for any heteroscedasticity problems that might be present among cross-sections. The regression results are presented in Table 4.

\subsection{Findings}

The adjusted $R^{2}$ of $86 \%$ indicates a high explanation power of independent variables of the model. The sign and the significance of IFRSDummy variable tests the hypotheses of the study. IFRSDummy variable which is the focus of interest of the study was found significant, and its sign is negative as expected. This indicates that mandatory adoption of IFRS by companies caused a decrease in their cost of debt. The coefficient for LogSales variable which controls the size effect on the cost of debt was found significantly positive which suggests that larger firms' cost of debt are higher than those of smaller firms. This finding is not as expected in the literature because intuitively larger firms are thought to achieve cheaper funds more easily than their small counterparts. Tangibility variable which proxies the collaterals available in case of default of the debt is found significant and its coefficient has a negative sign as expected. Cost of debt decreases as firms have more covenants in case of default. The second variable of which sign is found contrary to what was expected is the CurrRatio. The coefficient for CurrRatio variable which controls effect of the liquidity on the cost of debt was found significant and has a positive sign. LogIntCov variable which shows how many times a firm can pay its interest expenses by its earnings before interest and taxes (EBIT), was found inversely related to cost of debt. This result is in line with theoretical and intuitive expectations. The only variable which was not found significant is the SDNetlnc which was the measure of firm-specific risk. The macroeconomic control variable GDPGrowth was found significant and positively associated with the 
cost of debt. IntRate variable which was measured as the upper-bound for annual interest rate allowed by the Central Bank of Turkey for time deposit up to 6 months was also found significant and positively associated with the cost of debt.

Table 4. Regression Results

\begin{tabular}{|c|c|c|c|}
\hline & Predicted Sign & Coefficients & t-Statistic \\
\hline \multicolumn{4}{|l|}{ Dependent variable } \\
\hline \multicolumn{4}{|l|}{ CostofDebt } \\
\hline \multicolumn{4}{|l|}{ Independent variables } \\
\hline IFRSDummy & $?$ & -0.024 & $-4.175 * * *$ \\
\hline LogSales & - & 0.058 & $6.532 * * *$ \\
\hline Tang & - & -0.143 & $-4.158 * * *$ \\
\hline CurrRatio & - & 0.023 & $6.329 * * *$ \\
\hline LogIntCov & - & -0.033 & $-13.761 * * *$ \\
\hline SDNetInc & + & -0.003 & -1.079 \\
\hline GDPGrowth & & 0.010 & $11.716^{* * *}$ \\
\hline IntRate & + & 0.009 & $20.728 * * *$ \\
\hline $\mathrm{C}$ & & -0.334 & $-5.265 * * *$ \\
\hline Adjusted R-squared & \multicolumn{3}{|l|}{0.862} \\
\hline Sample & \multicolumn{3}{|l|}{$2002-2008$} \\
\hline Periods included & \multicolumn{3}{|l|}{7} \\
\hline Cross-sections included & \multicolumn{3}{|l|}{138} \\
\hline Total panel (unbalanced) observations & \multicolumn{3}{|l|}{646} \\
\hline Durbin-Watson Statistic & \multicolumn{3}{|l|}{1.939} \\
\hline Skewness of Residuals & \multicolumn{3}{|l|}{0.278} \\
\hline Kurtosis of Residuals & \multicolumn{3}{|l|}{2.341} \\
\hline \multicolumn{4}{|c|}{$\begin{array}{l}\text { Equation } 1 \text { is estimated by using Panel EGLS (Cross-section weights). "CostofDebt" is the interest expense } \\
\text { divided by average total debt. IFRSDummy takes the value of } 1 \text { for the post-IFRS period and } 0 \text { otherwise. } \\
\text { "LogSales" is the log of total sales. "Tangibility" is the ratio of the net of property, plant and equipment to total } \\
\text { assets. "CurrRatio" is the current assets divided by current liabilities. "LogIntCov" is the log of earnings before } \\
\text { interest and taxes (EBIT) divided by the interest expense. "LogSDNetInc" is the log of the standard deviation } \\
\text { of net income over the rolling prior three-year period. GDPGrowth is the annual percentage growth rate of } \\
\text { GDP at market prices based on constant local currency. IntRate is the upper-bound for annual interest rate } \\
\text { allowed by the Central Bank of Turkey for time deposit up to } 6 \text { months. }\end{array}$} \\
\hline
\end{tabular}

\section{Conclusion}

The main hypotheses of whether mandatory adoption of IFRS caused a decrease in cost of debt was tested for the sample of Turkish manufacturing firms between years 2002 and 2008 . This paper contributes to the literature by providing evidence on the economic consequences of mandatory IFRS adoption on the cost of debt for the first time for Turkish manufacturing firms.

The main finding of this paper presents a favorable effect of mandatory IFRS adoption on the cost of debt of Turkish manufacturing firms. The average cost of debt for the sample firms decreases significantly after IFRS adoption year. This finding contradicts the findings of Moscariello et al. (2014) in that they found no effect of mandatory adoption on the cost of debt in Italy and the UK. Nevertheless, they report that the debt-contracting process in Italy improved after mandatory IFRS adoption. They explain their results for the UK by its having similar standards to IFRS before adoption. They explain no effect result for Italy by its having weak enforcement regime. Either of these two explanations cannot characterize Turkey's case properly. First, Florou and Kosi (2015) argue that benefits of IFRS adoption would be sounder when differences between 
local financial reporting standards and IFRS are larger. Turkey's local GAAP is a rule-based, tax oriented and rigid reporting system and has hardly similarities with the principles-based nature of IFRS. Thus firms adopting IFRS are expected to take advantages of better disclosure and a better reflection of the financial situation in their financial reports when compared to countries like the UK. Second, Capital Markets Board of Turkey which regulates and governs public companies cannot be defined as weak legal enforcement. Last but not least the importance of better disclosure would relatively be higher in the situations of greater market uncertainty (Sengupta, 1998). Given these facts lower cost of debt after IFRS adoption is not a surprise for Turkish firms.

Analysis results revealed that the cost of debt of Turkish manufacturing firms is negatively related to the availability of tangible assets and to the interest coverage ratio as hypothesized. Moreover, firm size as measured by the log of sales and the current ratio is positively associated with the cost of debt which is the opposite of what was hypothesized.

This study is not free from limitations. First of all, like all studies, the results are as correct as the proxies used to measure economic phenomenon. Although the most common measures were chosen in this paper, they are all subject to measurement errors by nature. Cost of debt variable, which is measured by the interest expense to average debt, is a static measure of the cost of debt, which captures not only this year's debt contracts but also those of previous years in case of long-term debt financing. The standard deviation of net income was used as the measure of uncertainty in this paper. This variable would be less measurement error-free if it were estimated during a longer period than three years like in this paper. The three year period of pre and post-IFRS adoption year used in analyses may be prolonged in future studies. The analyzed period ended in 2008, so the analyses do not reflect the effect of changes in borrowing rates following the crises in 2008. Dramatic changes in interest rates in post-crisis years might affect the conclusions. Following the literature, the upper-bound for annual interest rate allowed by the Central Bank of Turkey for time deposit up to 6 months was used to control the effect of interest rates on the cost of debt. Although this measure is thought to capture the variations in interest rates, using alternative definitions of interest rates will add more robustness to the study.

\section{References}

Adıgüzel, H. (2017). Türkiye'de uluslararası finansal raporlama standartlarına uyumun firmaların kazanç kalitesi üzerine etkisi. Muhasebe ve Denetime Bakis/Accounting \& Auditing Review, 17(51), 103-114.

Ağca, A., \& Aktaş, R. (2007). Uluslararası muhasebe/finansal raporlama (IAS/IFRS) standartları iMKB'de yer alan firmaların finansal tablolarını nasıl etkiledi?. Dumlupınar Üniversitesi Sosyal Bilimler Dergisi, 18, 1-16.

Alkan, G. İ., \& Doğan, O. (2012). Uluslararası finansal raporlama standartlarının finansal rasyolara kısa ve uzun dönemli etkileri: iMKB'de bir araştırma. Muhasebe ve Finansman Dergisi, (54), 87-100.

Armstrong, C. S., Barth, M. E., Jagolinzer, A. D., \& Riedl, E. J. (2010). Market reaction to the adoption of IFRS in Europe. The Accounting Review, 85(1), 31-61.

Balsari, C. K., \& Varan, S. (2014). IFRS implementation and studies in Turkey. Accounting and Management Information Systems, 13(2), 373-399.

Balsari, C. K., Özkan, S., \& Durak, G. (2010). Earnings conservatism in pre and post-IFRS periods in Turkey: Panel data evidence on the firm-specific factors. Accounting and Management Information Systems, 9(3), 403-421.

Baltagi, B. (2005). Econometric analysis of panel data. John Wiley \& Sons.

Bozcuk, A. E. (2012). Performance effects of early IFRS adoption by Turkish firms. World of Accounting Science, 14(3), 112.

Dalcı, I., \& Özyapıcı, H. (2017). Analysis of the impact of first-time mandatory IFRS adoption on financial statements: The case study of the listed hotels in Turkey. Accounting \& Management Information Systems/Contabilitate si Informatica de Gestiune, 16(1), 5-29.

European Parliament (2002) European Community Regulation No. 1606/2002. Retrieved January 16, 2018 from http://eur-lex.europa.eu/LexUriServ/LexUriServ.do?uri=OJ:L:2002:243:0001:0004:en:PDF 
Florou, A., \& Kosi, U. (2015). Does mandatory IFRS adoption facilitate debt financing?. Review of Accounting Studies, 20(4), 1407-1456.

Florou, A., Kosi, U., \& Pope, P. F. (2017). Are International accounting standards more credit relevant than domestic standards?. Accounting and Business Research, 47(1), 1-29.

Francis, J., LaFond, R., Olsson, P., \& Schipper, K. (2005). The market pricing of accruals quality. Journal of Accounting and Economics, 39 (2), 295-327.

Gönen, S., \& Akça, N. (2014). Borçlanma maliyetlerinin Türkiye muhasebe standartları ve vergi mevzuatı kapsamında değerlendirilmesi. Siyaset, Ekonomi ve Yönetim Araştırmaları Dergisi, 2(3), 83-97.

Gürarda, Ş. (2013). IFRS adoption \& market reaction: Istanbul Stock Exchange case. International Journal of Business Management \& Economic Research, 4(6), 829-834.

Horton, J., Serafeim, G., \& Serafeim, I. (2013). Does mandatory IFRS adoption improve the information environment? Contemporary Accounting Research, 30(1), 388-423.

IASB (2007). IAS 23 Borrowing Costs, https://www.ifrs.org/issued-standards/list-of-standards/ias-23-borrowing-costs/

IFRS Foundation, Retrieved January 16, 2018 from http://www.ifrs.org/use-around-the-world/use-of-ifrs-standards-byjurisdiction/\#analysis

Karataş, M. (2010). Borçlanma maliyetlerinin UMS 23, Kobi'ler için UFRS ve Vergi Usul Kanunu kapsamında değerlendirilmesi. Mali Çözüm Dergisi/Financial Analysis, 98, 117-141.

Kargin, S. (2013). The impact of IFRS on the value relevance of accounting information: Evidence from Turkish firms. International Journal of Economics and Finance, 5(4), 71-80.

Kim, J.B., Tsui, J.S.L., \& Yi, C.H., (2011). Voluntary adoption of international accounting standards and loan contracting around the world. Review of Accounting Studies, 16(4), 779-811.

Kline, R. B. (2010). Principles and practice of structural equation modeling ( $3^{\text {rd }}$ ed.). New York, Guilford.

Küçüktüfekçi, M., \& Killi, M. (2016). Borçlanma maliyetlerinin muhasebelestirilmesi: TMS 23, Tekdüzen muhasebe sistemi ve Vergi Usul Kanunu çerçevesinde bir inceleme. International Journal of Management Economics \& Business, 12, 444-460.

Lee, Y. H., Kang, S. A., \& Cho, S. M. (2015). The effect of voluntary IFRS adoption by unlisted firms on earnings quality and the cost of debt: Empirical evidence from Korea. Journal of Business Economics and Management, 16(5), 931-948.

Lourenço, I. M. E. C., Branco, M. E. M. D. A., \& Castelo, D. (2015). Main consequences of IFRS adoption: Analysis of existing literature and suggestions for further research. Revista Contabilidade \& Finanças, 26(68), 126-139.

Moscariello, N., Skerratt L., \& Pizzo, M. (2014). Mandatory IFRS adoption and the cost of debt in Italy and UK. Accounting and Business Research, 44(1), 63-82.

Paglietti, P. (2009). Investigating the effects of the EU mandatory adoption of IFRS on accounting quality: Evidence from Italy. International Journal of Business and Management, 4(12), 3-18.

Sengupta, P. (1998). Corporate disclosure quality and the cost of debt. Accounting Review, 73(4), $459-474$.

Suadiye, G. (2012). Value relevance of book value \& earnings under the local GAAP and IFRS: Evidence from Turkey. Ege Akademik Bakis, 12(3), 301-310.

Şenyiğit, Y. B. (2014). Determinants of voluntary IFRS adoption. Accounting and Management Information Systems, 13(3), 449-465.

Terzi, S., \& Şen, i. K. (2013). Uluslararası finansal raporlama standartlarına geçişin özkaynak üzerine etkileri: Borsa İstanbul örneği. World of Accounting Science, 15(4), 1-19.

Türel, A. (2009). The value relevance of IFRS: The case of Turkey. Acta Universitatis Danubius. CEconomica, 5(1), 119128.

Verbeek, M., \& Nijman, T.E. (1992). Testing for selectivity bias in panel data models. International Economic Review, 33,681-703.

Wu, J. S., \& Zhang, I. X. (2014). The adoption of internationally recognized accounting standards: Implications for the credit markets. Journal of Accounting, Auditing \& Finance, 29(2), 95-128.

Zaidi, S., \& Paz, V. (2015). The impact of IFRS adoption: A literature review. The Journal of Theoretical Accounting Research, 10(2), 116-141. 